\title{
SDH Complex Mutation Analysis Testing Method
}

National Cancer Institute

\section{Source}

National Cancer Institute. SDH Complex Mutation Analysis Testing Method. NCI

Thesaurus. Code C158956.

A request to enter the specific molecular analysis method used to detect and identify mutations in any gene that encodes one of the proteins in the succinate dehydrogenase (SDH) complex.. 